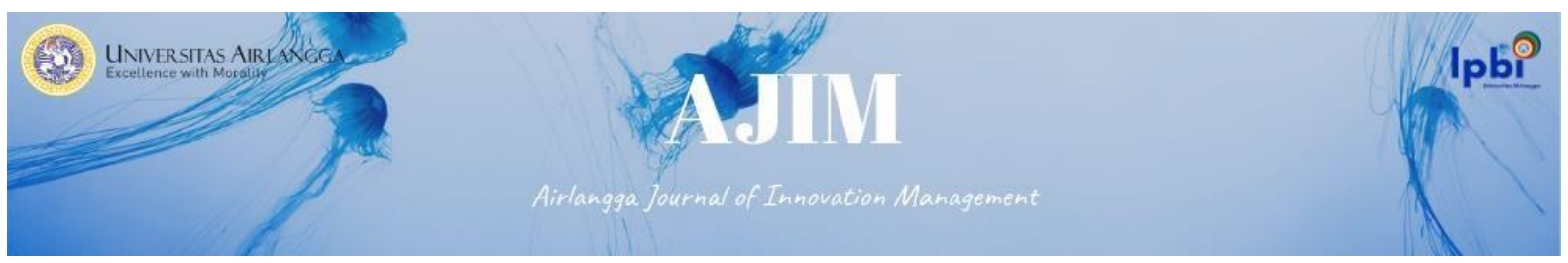

Vol. 2 No.2 Oktober 2021

e-ISSN: 2722-5062

DOI : 10.20473/ajim.v\%vi\%i.30696

\title{
EFFECTIVENESS OF DIGITAL PLATFORMS AS FOOD AND BEVERAGE MARKETING MEDIA DURING THE COVID-19 PANDEMIC
}

\author{
Ira Nur Hidayah ${ }^{a^{*}}$, Nur Fadhilatur Rohmah ${ }^{\text {b }}$, Muchammad Saifuddin ${ }^{\mathrm{c}}$ \\ a,b,c, Universitas Islam Negeri Sunan Ampel Surabaya \\ "Corresponding e-mail: iranurhidayah12@gmail.com
}

\begin{abstract}
Covid-19 pandemic disrupted business practices worldwide, especially in food and everage sector. Not a few business actors in this sector closed their business due to declining sales during pandemic. In responding to this global effect, business actors are not only encouraged to adapt. Still, they must also think of practical steps to stabilize sales as before through creative and innovative digital marketing strategies. Data collected by interviews and literature study to provide an in-depth analysis of condition of food and beverage during Covid-19 pandemic and provide education about digital marketing strategies that business actors can apply to increase food and beverage sales during Covid19 pandemic. The results showed that social media such as Instagram, Facebook, Twitter, and Whatsapps were effective in marketing food and beverage products. In addition, Shopeefood ecommerce platform and food delivery applications such as GrabFood and GoFood also play a significant role in success of food and beverage marketing and sales and can support government regulations to stay at home during the Covid-19 pandemic.
\end{abstract}

\section{Keywords: Online Platform, Marketing, Food and Beverage, Covid-19}

\section{Introduction}

Corona Virus Disease, better known as Covid-19, is a virus discovered in Wuhan, China, at the end of 2019. Covid-19 virus can spread in just one month to various countries in Asia, Europe, Africa, and America. Based on data from Indonesian Ministry of Health, total number of confirmed global Covid19 cases as of July 20, 2020, was 14,348,858 cases with an actual death of 603,691 (CFR 4.2\%) in 215 infected countries and 171 local transmission countries. The highest cases are in the United States, Spain, England, Italy, and France, while Indonesia is 25 (Amani, 2020 in Sukma, 2021). One form of Indonesian government's policy in suppressing increase in positive cases of Covid-19 is to implement Large-Scale Social Restrictions (PSBB). The policy regulates all forms of community economic and social activities by staying at home and restricting public facilities such as schools, colleges, markets, malls, places of worship, etc. Indonesia's culinary sector or Food and Beverage experienced a decline in daily sales, reaching 37\% during the pandemic (Burhan, 2020 in Sukma, 2021). This decline in sales is influenced by various factors, ranging from reasons people prefer to produce their own food and 


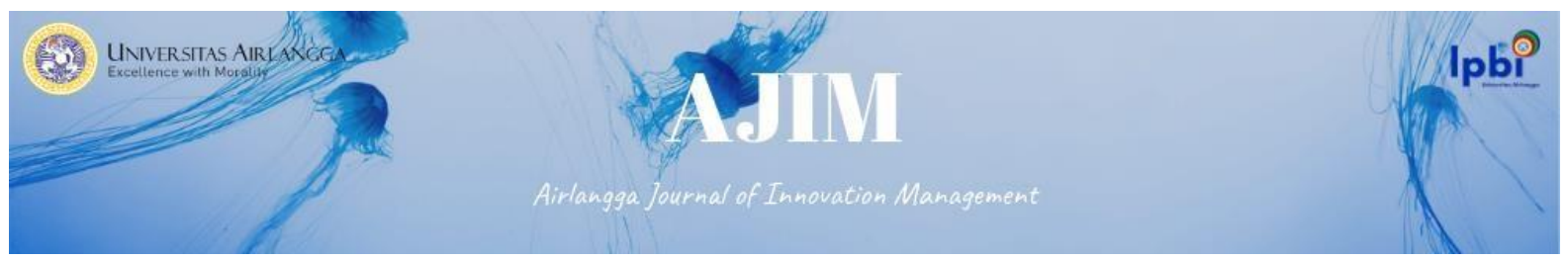

spend money until pandemic ends and limited outdoor movement due to implementation of PSBB policy.

Facing up declining Food and Beverage sector sales, specific strategies are needed to overcome these problems without violating government policies. The system is to market food and beverage products through digital platforms. The application of digitalization during Covid-19 pandemic positively impacted business world, especially in Food and Beverage industry. Digitization has brought about significant changes in marketing and sales of Food and Beverage. Indirectly, this marketing efficiency will increase sales so that economy will return to stability even though pandemic is still ongoing. This is in line with research conducted by (Heriawan et al., 2021), who concluded that advantage of doing sales and marketing online is getting a more comprehensive network and more consumers. The result of research (Al-hakim et al., 2021) states that digital flyers make marketing easier for a wider area because they use internet and don't cost money. However, digital marketing and sales of food and beverages are not in line with research by (Chowdhury et al., 2020). The study reveals several strategies, namely product rotation method (FEFO), to minimize impact of declining sales in the Food and Beverage sector. From these studies' differences, this research answers all the obstacles and difficulties entrepreneurs face in the Food and Beverage industry marketing their products during a pandemic.

\section{Literature Review}

A platform is a computer network that makes it easy to find services or goods to contributors or sellers (Puspita Ghany, 2016 in Ladita, 2020). This type, of course, is more directed towards an online sales platform that operates through a website system. Digital platforms used by most business people are e-commerce platforms, including Tokopedia, Bukalapak, Lazada, and Shopee. These business people use these platforms to attract customers to have products they sell. In addition, every business person also uses other digital platforms, namely digital social media platforms, including Whatsapp, Instagram, Facebook, Twitter, and Tik-Tok. By utilizing digital media, business people can promote their products through these platforms, so that as a result, they can develop the business they started. The sector is a business environment. So, the food and beverage sector is a business environment where all companies produce added-value products. In addition, this sector is related to cooking, so it concluded that this sector has a significant role in everyday human life because it has produced food for the community.

\section{Methods/Materials}

The research methods used are interviews and literature study. The data used in this study was obtained from interviews conducted by researchers on 2021. Researchers conducted interviews about condition of Food and Beverage industry during Covid-19 pandemic and the extent of role of digital platforms as a medium of marketing and sales. The subjects of this interview are business people engaged in field of Food and Beverage, including Nurlita T.W, founder of Bakaran Sobat Sidoarjo, and Krysna A.F as owner of Ayam Geprek Uhuyy. Some of strategies used by these two business sectors are utilizing social media, collaborating with Grab and Gojek, providing special promos, and using Word of Mouth Marketing (WOM) strategy.

The second research method is a literature study. The research was carried out by researchers searching for journals through internet site pages and then reviewing journals found. To understand how researchers conducted a literature review in this study, researchers attached the illustration in Figure 1. The journals obtained by researchers came from Google Scholar for national journals and 


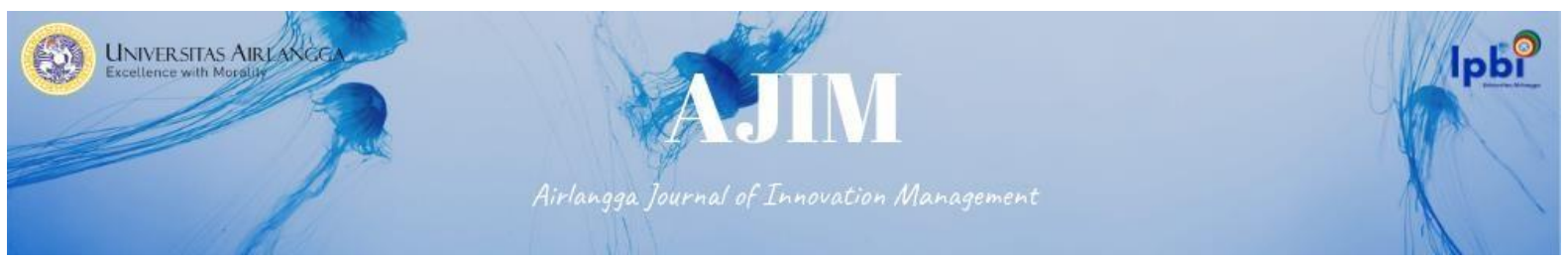

ReasearchGate for international journals. Researchers use journals published in 2020 and 2021. The journal criteria used by researchers are journals that examine business conditions in Food and Beverage sector during Covid-19 pandemic and implementation of marketing strategies in industry. At first, authors found as many as 33 journals related to food and beverage sector and COVID-19. Then author reviews these journals by reading abstract section of all journals and gets 29 related journals related to topic in this article. However, number was reduced to 27 after researchers conducted a review by reading abstract and entire contents of journal.

\section{Figure 1. Interview process and selection of journals}

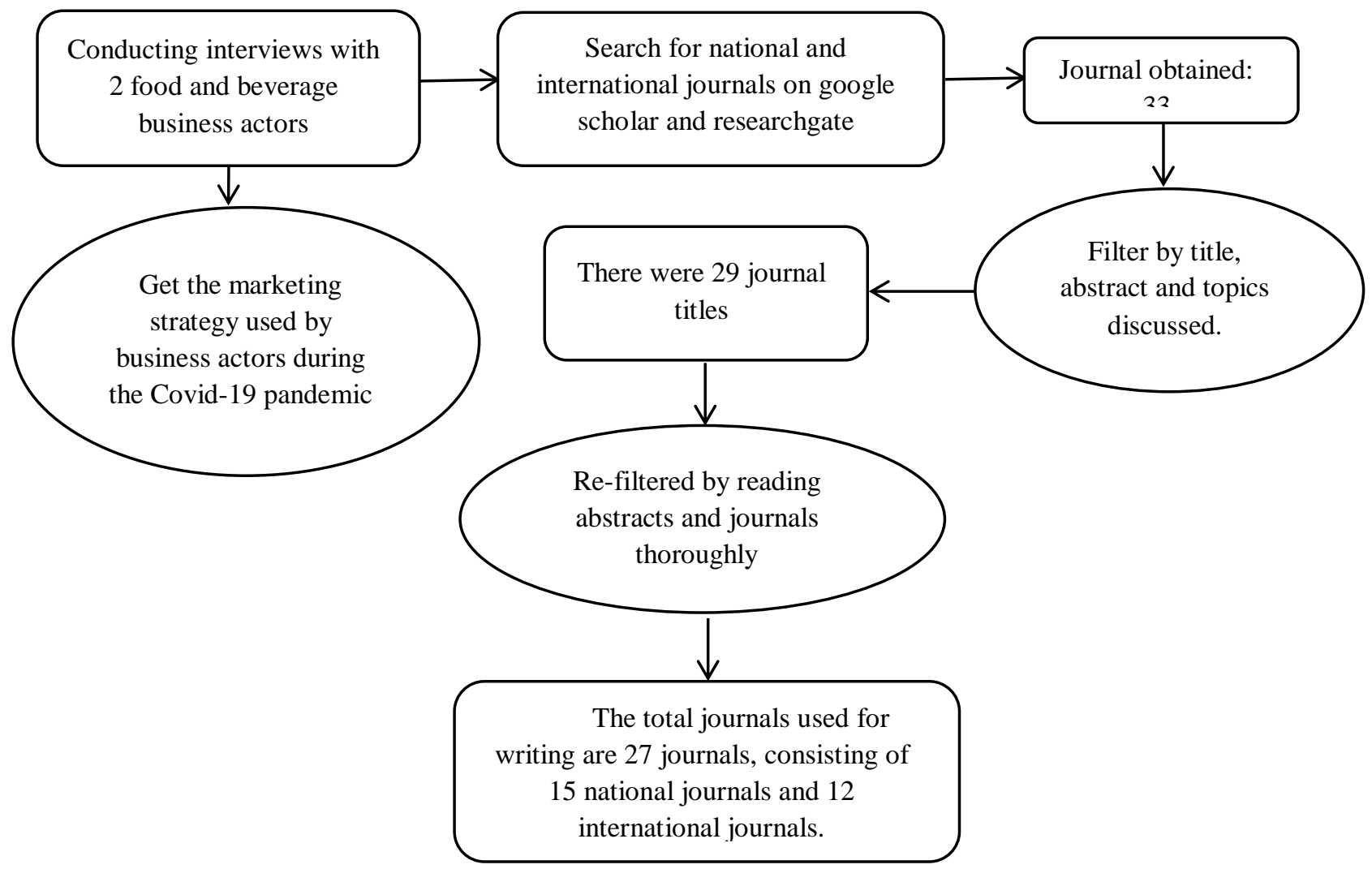

Source: Research process (2021)

\section{Results and Discussion}

Based on results of interviews conducted by researchers to Krysna A.F as owner of "Ayam Geprek Uhuyy" and Nurlita W. as business owner of "Bakaran Sobat" on June 2021, several strategies were carried out. Both businesses engaged in Food and beverage sector have same marketing strategy to increase sales volume and business income during Covid-19 pandemic. The strategy in question is digital marketing strategy. The digital marketing strategy implemented by "Ayam Geprek Uhuyy" is to utilize Facebook social media for sales promotion media and also use Word of Mouth Marketing (WOM) to introduce and promote Ayam Geprek Uhuy. While strategy used by "Bakaran Sobat" in its advertising using social media Facebook, Instagram, and Tiktok, using the buy 4 get 1 system, providing free drinks for purchase of at least four foods, in collaboration with GrabFood and GoFood, has two business branches and uses Word of Mouth Marketing (WOM) through Whatsapps to promote your Bakaran products. 


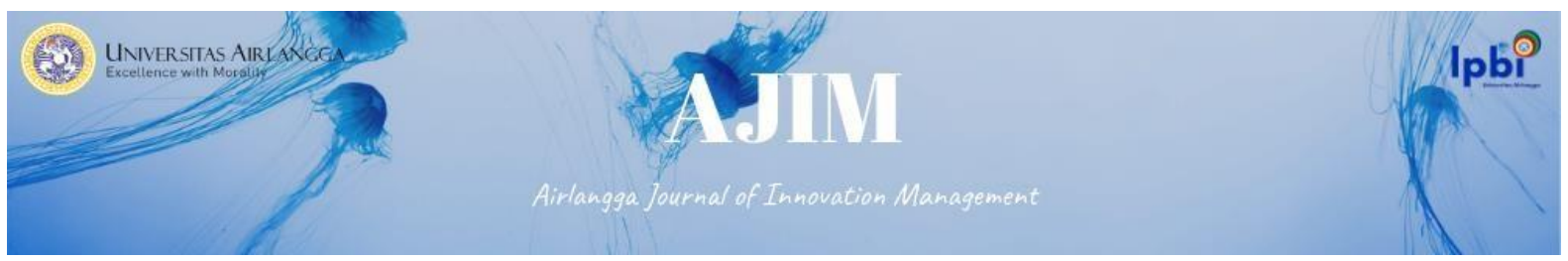

In addition, based on several journals that researchers have found, it can be known that majority of businesses at home and abroad have indirectly implemented several points of marketing communication mix related to promotion, which consists of 8 main communication models namely advertising; sales promotion; events and experiences; public relations and publicity; direct marketing; interactive marketing, Word Of Mouth marketing and personal sales (Philip \& Lane Keller, 2016). From literature review of several journals, these researchers examined condition of Food and Beverage during Covid-19 pandemic and marketing strategies implemented. The first marketing strategy carried out by Food and Beverage businesses is to create a modern branding image packaging, maximizing online and digital marketplace so that consumers can still reach products during Covid-19 pandemic (Mandira et al., 2020). The second marketing strategy is to utilize social media such as Whatsapps, Instagram involving Celebrity Endorser, Twitter, Facebook, and certain websites, including inspiring websites. In addition, it also uses weakness opportunity strategies as well as selling and marketing online, utilizing Google Business features and providing discounts and free delivery promotions on every purchase of at least 3 products (Syaiful, 2020 ; Heriawan et al., 2021 ; Hendriyati \& Santoso, 2021 ; Wulandari et al., 2020 ; Rosi et al., 2020 ; Rahmana et al., 2021 ; Ari Kadi et al., 2021 ; Saputra, 2021 ; Gerritsen et al., 2021 and Ramli et al., 2021).

The third marketing strategy is to install and activate GoFood services to promote and sell products, cooperate with Grab and Gojek services for food delivery, online brochure creation and also provide discounts for GoFood and Shopeefood users, and implement sales on take away, delivery order, pick-up, drive-through and also use online food delivery platform (OFD) while offering special offers (Junus et al., 2020 ; Setyowati \& Tutiasri, 2021 ; Al-hakim et al., 2021 ; Sukma, 2021 ; Yilmaz \& Şahin, 2021 and Horta et al., 2021). The fourth marketing strategy is to include license number of innovating with various flavor variants, not using harmful and safe to consume materials, and using common hashtags to make customer appeal increase (Astutik et al., 2021 and White et al., 2020). The fifth marketing strategy is to enhance knowledge and skills of partner groups by introducing technological innovation. Those skills include digital skills, operational and training skills, supply chain skills, digital marketing skills and also Health Safety Environment (HSE) skills (Abdullah et al., 2020 and Telukdarie et al., 2020). The sixth marketing strategy is to focus on using e-commerce specifically to improve access to nutritious and healthy food, for example, by prioritizing healthy products through direct delivery channels to new consumers that have been established for some brands, while also utilizing responsible marketing (Atni, 2020 ; Yusoff et al., 2021 and Sultana \& Islam, 2020). And last marketing strategy is to do digital transformation, where the service becomes more personal and focused on customers with more creative service offerings (Memon et al., 2021 ; Wood et al., 2021 ; and Hoekstra \& Leeflang, 2020).

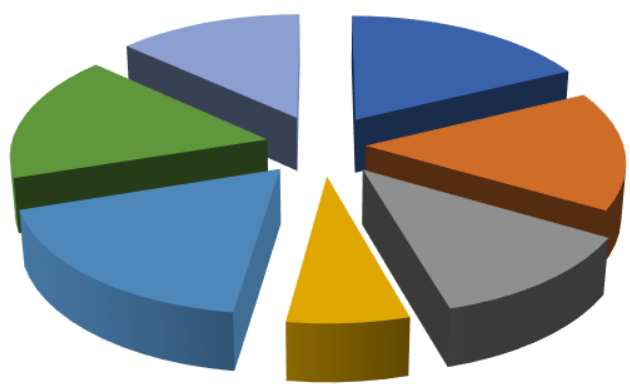

\author{
- Instagram \\ - Facebook \\ WhatsApp \\ Twitter \\ Grabfood \\ Gofood \\ Shopeefood
}




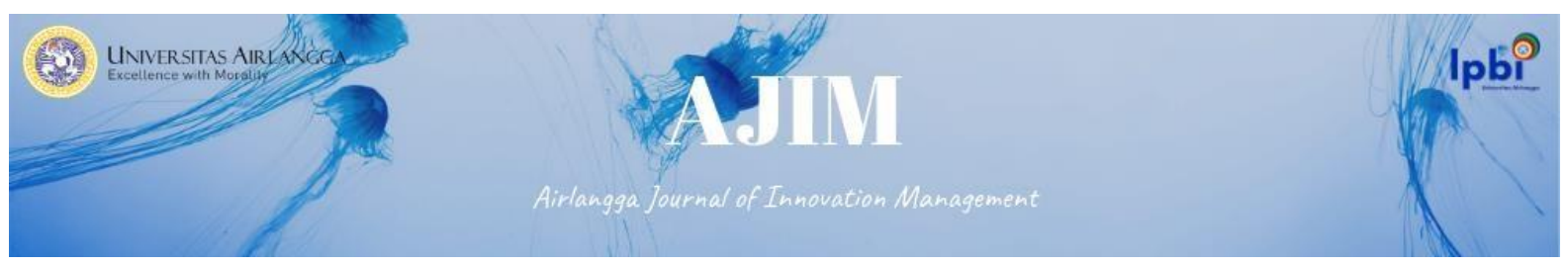

Figure 2. Digital Marketing Media

\section{Source : Result of Interviews and 27 Literature Reviews}

From interviews conducted by two food and beverage business actors and 27 literature reviews, Figure 2 shows that as many as $80 \%$ of business actors in food and beverages sector use Instagram social media for marketing their products; this is supported by research. (Mandira et al., 2020) which states that Instagram ads are very effective in providing advertising services to highlight a product on social media page. In addition, the benefits of social media Instagram are also felt by Kamsia Boba's efforts in research (Syaiful., 2020) who explained that Kamisa Boba's business turnover increased after implementing promotions through Instagram social media. (Al-hakim et al., 2021)In Instagram social media, there is a separate strategy that can be applied by business actors, namely by using Key Opinion Leaders (KOL) by using the services of Celebrity Endorser, which is commonly called "celebgram". The role of celebgram is to make products/services easily recognizable by the wider community or followers of celebgram. The use of creative and interactive celebgrams will also attract more attention so that their followers will be influenced to use or buy promoted products. (Al-hakim et al., 2021) also explained that Instagram can be used as an interactive marketing method to consumers by using surveys and polls about products or services in food and beverages business. This method is considered able to increase number of followers of business's Instagram account and can increase sales in Food and Beverage sector during the Covid-19 pandemic.

After Instagram, Facebook is ranked 2nd for social media promotion with most number of users, which is $70 \%$ (Rosi et al., 2020) mentioned that Facebook plays an important role in starting a business because by utilizing social media such as Facebook, products will be more easily reached by wider community and make it easier for sellers and buyers to be able to communicate and share information about the products being marketed.

Next is WhatsApp, as many as 55\% of Food and Beverages businesses use WhatsApp to promote their products during the Covid-19 pandemic. As the Taichan Satay Restaurant "Fried" did in research (Al-hakim et al., 2021) explained that "Fried" Taichan Sate Restaurant applies direct marketing and personal selling marketing strategies to market products to consumers. The database in form of customer telephone numbers was obtained through Customer Care Team of "Fried" Sate Taichan Restaurant. The implementation of this strategy makes the Sate Taichan "Fried" Restaurant experience an increase in turnover. This shows a shift in consumer behavior because they prefer to transact online rather than offline, especially during the Covid-19 pandemic. The marketing method using WhatsApp is also carried out by business actors in the Food and Beverages Sector in Bogor City. In (Susilowati, 2021) Promotion using the WhatsApp application where WhatsApp groups can be used to promote culinary products provided by MSME actors, several MSME communities form groups to exchange information and market their respective culinary products. Then proceeded with contacting personally and agreed on payment and delivery process. Payment can be made by Cash On Delivery (COD) and transfer.

Furthermore, there is a marketing strategy through Twitter media, picture above shows that as many as $30 \%$ of business actors in food and beverage sector use social media through this social media, business actors often share or post their products in comment column of accounts that have many followers and create hashtags to get accessible to a wider network. However, marketing through Twitter is considered less interactive, especially in the Food and Beverage sector.

In addition to social media as a tool for marketing communications, other e-commerce platforms can also be an effective way to market and sell Food and Beverage products. According to the results of interviews conducted by researchers with two food and beverage business actors in the city of Surabaya, as well as based on several literature reviews obtained by researchers, the most widely used e-commerce platform by business actors in marketing their products is Grabfood, as many as $80 \%$ of business actors Food and Beverages sells its products through Grab food. Based on results of an in- 


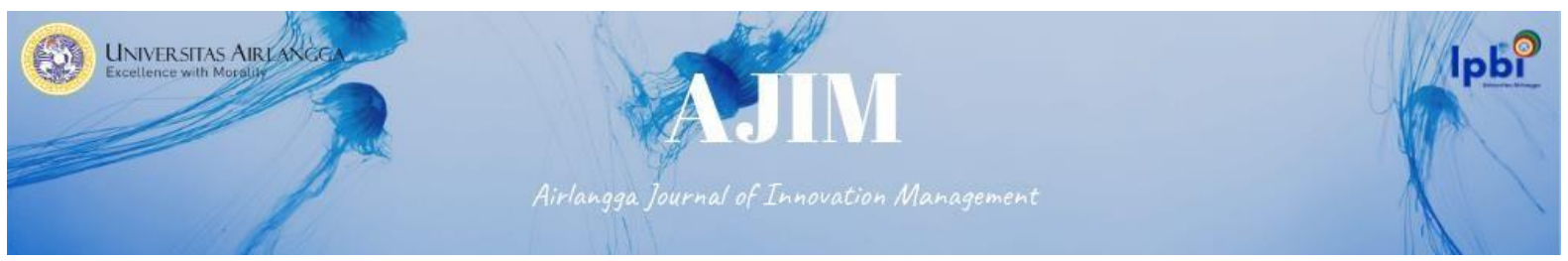

depth analysis of the food delivery industry, Grab ranks first for food delivery services in Southeast Asia, with 6 billion users. Momentum Works COO Yorlin Ng said Grab is focused on reducing costs to attract more users. In addition, Grab is also upgrading the core infrastructure of delivery services and focusing on fraud management to partnerships. Next is Gofood, 75\% of Food and Beverages business actors sell their products through Gofood. With large discounts and free shipping features, this platform is in great demand by the public, especially millennials at time of restrictions on activities outside home due to Covid-19 pandemic. Not much different from GrabFood and GoFood, Shopeefood also increasingly exists in food delivery, even though there are two big competitors. As many as $60 \%$ of Food and Beverages businesses join Shopeefood to market their products. Based on interviews conducted by researchers with two food and beverages business actors, sales have increased since shopeefood because Shopeefood provides discounts and free shipping every day to customers and effortless payment methods. By utilizing digital, food and Beverage marketing strategies can facilitate business actors to market and sell their products effectively and efficiently. During this pandemic, both Grabfood, Gofood, and Shopeefood offer various discounts and free shipping for their users. With this platform, consumers also get convenience in ordering and delivering food and beverages, especially when government regulations require people to stay at home.

Although digital marketing is very dominant in this era, this strategy cannot be separated from things that can support digital marketing carried out by Food and Beverage business actors both at home and abroad, namely by implementing the 4C marketing mix.(Robert F. Lauterborn, 1990 in Al-hakim et al., 2021) explained that $4 \mathrm{C}$ Marketing is a marketing system that is able to provide a positive correlation because consumer needs are prioritized in it. 4C marketing consists of customers (consumers) easily getting what they need safely and practically, in terms of convenience (comfort), including product quality that can be adjusted to consumer needs, including always fresh prioritizing taste, cost (price), which is always displayed on informative food menu explanations on social media and applications so that the messages conveyed are easy to understand. Food and Beverage business actors are also trying to maintain communication (communication) so that they are maintained through soft-selling promotions through other social media. From the study results, most of business actors have implemented 4C marketing in their business.

\section{Conclusion}

The results and discussion above concluded that digital platforms have effectiveness in marketing and selling food and beverage; In obtaining a more comprehensive network, social media is one of effective ways to market food and beverage products both at home and abroad during Covid-19 pandemic. The use of influencers or celebrity endorsements can influence consumers to use or consume products consumed by them. Sales of products that use services of influencer or celebrity endorsement will continue to increase. Discounts or promotions given can attract consumers to buy these products. The free shipping offer provided by Shopeefood, Grab food, and Gofood is a powerful enough strategy to attract consumers. Many business actors have risen or started new businesses through digital marketing during Covid-19 pandemic because digital marketing can streamline marketing, so sales in Food and Beverage sector can continue to increase. Further research can use more interviews with food and beverages business operators so that researchers can also provide solutions to problems found in food and beverages business entrepreneurs. In other side, digital marketing platform also can develop its services to make it easier for food and beverages business actors to sell their products. Also for food and beverages business actors can take digital promotion discussed to maximize their selling in new normal condition right after pandemic. 


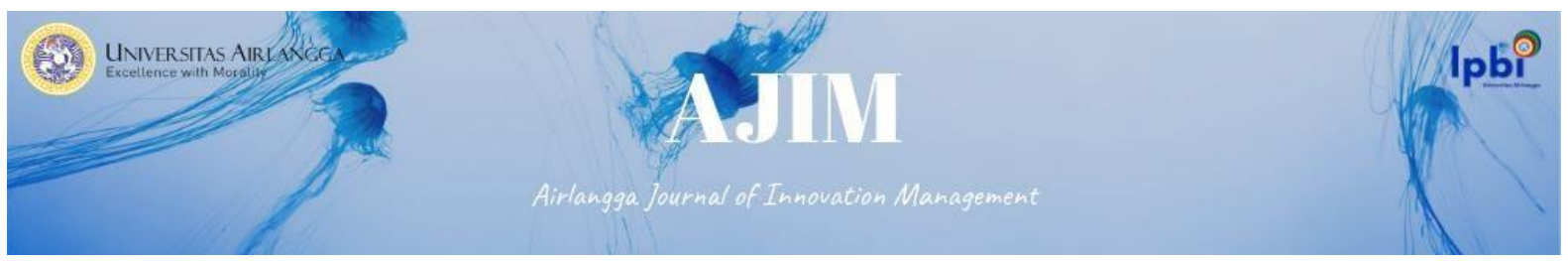

\section{References}

Abdullah, S., Daud, L., Bunyamin, \& Purwanti, R. E. (2020). Pengembangan Dan Pemasaran Online Produk Aneka Olahan Ikan Sebagai Sumber Pendapatan Altenatif Wanita Nelayan Di Masa Pandemi Covid -19 Di Kelurahan Purirano Kota Kendari. Conference on Innovation and Application of Science and Technology (CIASTECH 2020) Universitas Widyagama Malang, 02 Desember 202, Ciastech, 1309-1318.

Al-hakim, N., Komunikasi, F., Komunikasi, I., \& Indonesia, C.-. (2021). Menata Ulang Bisnis F \& B Pasca Pandemi ( Studi Kasus: Strategi Komunikasi Pemasaran Sate Taichan “ Goreng ”) Reimagining F \& B Business Post-Pandemic (Study Case: Sate Taichan “ Goreng ” Marketing Communications Strategy ) Health peraturan Pembatasan . 3(2).

Ari Kadi, D. C., Fauzi, R. U. A., Riziq, K. A., Pamungkas, A., \& Rossanto, S. A. R. (2021). Inovasi Strategi Pemasaran Sentra Industri Brem Madiun Dalam Menghadapi Persaingan di Masa Pandemi Covid 19. Indonesia Berdaya, 2(2), 87-95. https://doi.org/10.47679/ib.202161

Astutik, E. D., Silalahi, C. F., Azizah, A. I., Nur, E., \& Gista, Syeren Al dan Alfarizi, R. (2021). Strategi Bisnis "CEJEDW FROZEN FOOD" Pada Masa Pandemi Covid-19. Jurnal Bisnis Dan Kajian Strategi Manajemen, 5(1), 14-29. http://jurnal.utu.ac.id/jbkan/article/view/3047

ATNI. (2020). Nutrition responses from food and beverage companies to the Covid-19 pandemic. Report 2: An acute response. October. https://accesstonutrition.org/app/uploads/2020/10/SecondCovid-19-Quarterly-Report-Final-Version.pdf

Chowdhury, M. T., Sarkar, A., Paul, S. K., \& Moktadir, M. A. (2020). A case study on strategies to deal with the impacts of COVID-19 pandemic in the food and beverage industry. Operations Management Research. https://doi.org/10.1007/s12063-020-00166-9

Gerritsen, S., Sing, F., Lin, K., Martino, F., Backholer, K., Culpin, A., \& Mackay, S. (2021). The Timing, Nature and Extent of Social Media Marketing by Unhealthy Food and Drinks Brands During the COVID-19 Pandemic in New Zealand. Frontiers in Nutrition, 8(March), 1-13. https://doi.org/10.3389/fnut.2021.645349

Hendriyati, L., \& Santoso, I. B. (2021). Strategi Pemasaran Food and Beverage Untuk Meningkatkan Penjualan Pada Masa Pandemi Covid-19 Di Cavinton Hotel Yogyakarta, Indonesia. Journal of Tourism and Economic, 4(1), 60-72. https://doi.org/10.36594/jtec.v4i1.111

Heriawan, F., Susanto, A. B., \& Haryanti, D. (2021). Strategi Pemasaran , Penjualan dan Produksi Olahan Rumput Laut Berbasis IT saat Pandemi Covid-19 di Padepokan Suket Segoro Semarang. 10(1), 138-146.

Hoekstra, J. C., \& Leeflang, P. S. H. (2020). Marketing in the era of COVID-19. Italian Journal of Marketing, 2020(4), 249-260. https://doi.org/10.1007/s43039-020-00016-3

Horta, P. M., Matos, J. D. P., \& Mendes, L. L. (2021). Digital food environment during the coronavirus disease 2019 (COVID-19) pandemic in Brazil: An analysis of food advertising in an online food delivery platform. British Journal of Nutrition, 126(5), 767-772. https://doi.org/10.1017/S0007114520004560

Junus, M., Wijayanti, R. A., Marya, D., Yoga, S. W., Suharto, N., \& Hidayanti, N. (2020). Strategi Penjualan Makanan Memanfaatkan Fitur Layanan Go-Food pada Aplikasi Gojek untuk Pedagang Kecil \& Menengah di Masa Pandemi Covid-19. Prosiding Seminar Nasional Abdimas Ma Chung, 


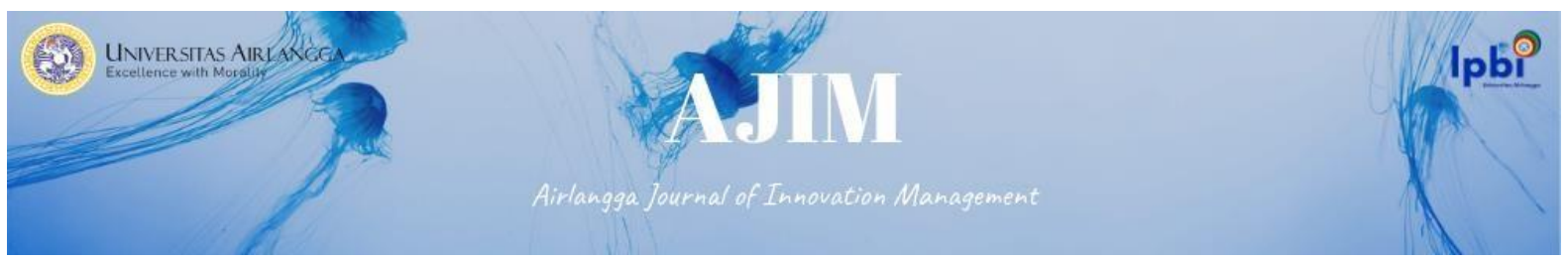

$191-202$.

Ladita, P. (2020). Analisis penerapan aplikasi android tokocrypto menggunakan pendekatan design thinking dibantu dengan platform design toolkit v.2.

Mandira, A., Swikno, S., Fadilah, M., \& Sunaryo, D. (2020). Strategi Marketing Teh Rempah "Uwuhable" Di Era Urbanisme Dan Pandemi covid-19. Inovasi Manajemen Dan Kebijakan Publik, 3(2), 14-24.

Memon, S. U. R., Pawase, V. R., Soomro, M. A., \& Pavase, T. R. (2021). Investigation of covid-19 impact on the food and beverages industry: China and India perspective. Foods, 10(5), 1-28. https://doi.org/10.3390/foods10051069

Philip, K., \& Lane Keller, K. (2016). Marketing Management (15th ed.). Pearson Education,Inc.

Rahmana, A., Fauzi, M., \& Suyono, A. M. (2021). PENDAMPINGAN STRATEGI PEMASARAN DIGITAL PRODUK MAKANAN DALAM Abstrak. 4(1), 49-57.

Ramli, N., Abd Ghani, F., Nawawi, W. N. W., \& Abd Majid, H. A. M. (2021). Intention to Use Online Food Ordering Services Among Universities Students During COVID-19 Pandemic. International Journal of Academic Research in Business and Social Sciences, 11(13), 394-405. https://doi.org/10.6007/ijarbss/v11-i13/8556

Rosi, M., Makruf, M., Teknik, F., \& Madura, U. I. (2020). Pemanfaatan Media Sosial Untuk Penjualan Kue Kering Bangkit Kacang Di Era Pandemi Covid-19 Di Desa. 42-46.

Saputra, D. (2021). Komunikasi Pemasaran Bisnis Kuliner Menggunakan Media Sosial Instagram di Era COVID-19. Voxpop, 3(1), 20-28.

Setyowati, N. D., \& Tutiasri, R. P. (2021). Strategi Komunikasi Pemasaran Bagi Pelaku Usaha Makanan yang Terkena Dampak COVID-19. JISIP : Jurnal Ilmu Sosial Dan Ilmu Politik, 10(1), 73-84. https://doi.org/10.33366/jisip.v10i1.2268

Sukma, T. (2021). Jurnal Ekonomi dan Bisnis Dharma Andalas Dampak Pandemi Covid-19 Terhadap Bisnis Kuliner dan Strategi Beradaptasi di Era New Normal. Bisnis Dharma Andalas, 23(1), 5163.

Sultana, S., \& Islam, A. (2020). Role of e-commerce for the survival of food service industry during covid-19.

Syaiful, F. F. (2020). Manajemen Entrepreneurship Education melalui pemasaran di tengah Pandemi covid-19: Studi kasus usaha minuman Kamsia Boba di Kabupaten Bangkalan. Jurnal Edukasi Nonformal, 2634(April 2020), 336-342.

Telukdarie, A., Munsamy, M., \& Mohlala, P. (2020). Analysis of the impact of covid-19 on the food and beverages manufacturing sector. Sustainability (Switzerland), 12(22), 1-22. https://doi.org/10.3390/su12229331

White, M., Nieto, C., \& Barquera, S. (2020). Good Deeds and Cheap Marketing: The Food Industry in the Time of COVID-19. Obesity, 28(9), 1578-1579. https://doi.org/10.1002/oby.22910

Wood, B., Williams, O., Nagarajan, V., \& Sacks, G. (2021). Market strategies used by processed food manufacturers to increase and consolidate their power: a systematic review and document analysis. Globalization and Health, 17(1), 1-23. https://doi.org/10.1186/s12992-021-00667-7 


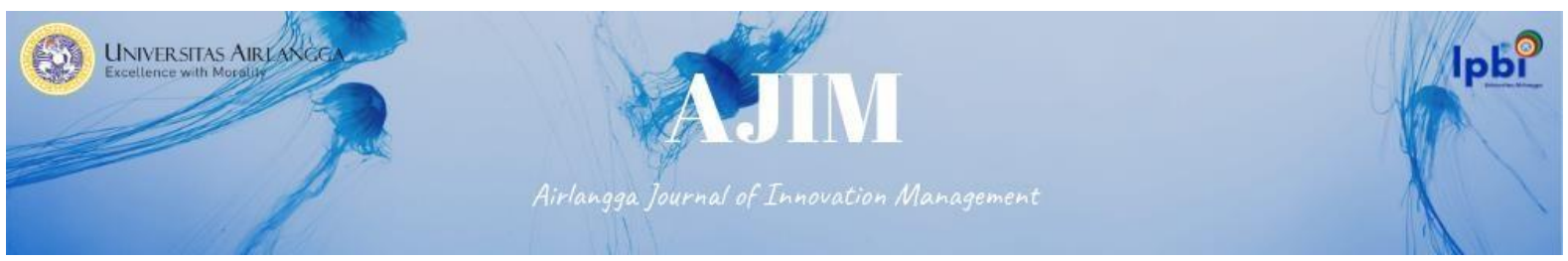

Wulandari, E., Riyanto, B., Munib, J. A., Adib, A., \& Suharto, M. (2020). DIGITAL MEDIA SOSIAL UNTUK MEMPROMOSIKAN “ GEBLEK YU LASTRI ” DI DESA NANGGULAN KULON PROGO Esty Wulandari, Bedjo Riyanto , Jazuli Abdin Munib , Ahmad Adib , Tujuan dari Kegiatan PKM CSR ini memberikan pendampingan serta pelatihan tentang merek, visual. 3, 3036.

Yilmaz, G., \& Şahin, A. (2021). How does the COVID-19 outbreak affect the food and beverage industry in Turkey? Proposal of a holistic model. Journal of Foodservice Business Research, 24(6), 629-664. https://doi.org/10.1080/15378020.2021.1883216

Yusoff, M. H., Amayreh, K. T., Ismail, R. C., Hatamleh, A., Karim, R., Mohamed, R. R., \& Baker ElEbiary, Y. A. (2021). Food and beverage in covid-19, shopee in online shop brooklyn.Store. Annals of the Romanian Society for Cell Biology, 25(4), 7746-7753. 